\title{
POSSE DE NOVO PROFESSOR CATEDRÁTICO
}

Aos 25 de novembro de 1960 , em sessão da Congregação da Faculdade de Direito da Universidade do Paraná, presidida pelo Sr. Magnífico Reitor, Professor Flávio Suplicy de Lacerda, tomou posse da cadeira de Direito Judiciário Civil o Professor Catedrático Egas Dirceu Moniz de Aragão. Na oportunidade, foi o novo catedrático saudado pelo Professor José Nicolau dos Santos, que proferiu a seguinte oração:

"Anos passados, há quase duas dezenas de anos passados, nêste mesmo recinto, ao receber seu gráu de Doutor, eminente mestre de Direito Penal dizia as palavras que ainda hoje posso recordar e repetir: "Conquistando o doutorado, fazemo-lo com a nítida compreensão de que só o prestigiaremos com a continuidade dos nossos estudos. Não é um direito a desfrutar. É uma obrigação a cumprir".

Realmente, Sr. Prof. Egas Dirceu Moniz de Aragão, o pensamento referido de Laertes Munhoz é exato e convence-nos, quer pela evidência conceitual, quer pela jóia de estilo em que se fez memorado. Mais do que um direito, a láurea de uma cátedra jurídica consiste num dever imperativo e indeclinável de amar e sentir o Direito, de estudar e aprimorar o Direito, de ensinar e aplicar o Direito. Repetimos, sobretudo, de ensinar e aplicar o Direito.

Parecerá translúcido e incontroverso o que vimos de afirmar. Tornamos entretanto a repetir que nada é mais difícil, nada é mais exaustivo, nada é mais heróico do que saber ensinar e poder aplicar precisa e inexoràvelmente o Direito. Todo o contexto multimilenar da História, comprimido em síntese, reduz-se apenas a uma luta contínua da humanidade, dos povos, das classes, dos indivíduos, pela justa aplicação do Direito.

Tem pois V. Excia., Sr. Prof. Moniz de Aragão, diante de si, no dia festivo e solene de sua posse, a visão da extensa responsabilidade que assume o mestre perante seus discentes, o catedrático da Faculdade de Direito perante a sociedade e o Estado a que pertence, o jurista perante a ciência, o advogado perante o constituinte, o tratadista perante o povo que instrui, o magistrado perante a humanidade, desta humanidade que sempre clamou e ainda clama por Justiça. 
Dizia Frasímaco a Socrates, com menosprezo arrogante de quem empalma o aço agudo da espada, símbolo remoto da fôrça e do poder: "Justiça é a vontade do mais forte". Dizia César, vencedor de batalhas, contemplando as legiões de lanceiros: "A República é apenas uma palavra". Dizia Luís XIV precedido pelos seus batalhões de mosqueteiros: "O canhão é o último argumento dos reis". Dizia Bismark, resumindo o sonho atrevido de todos os absolutistas, em todos os tempos e lugares: "A fôrça prima sôbre o Direito".

Nada mais inverídico, nada mais enganoso, nada mais quimérico. A História Humana ressalta sempre a derradeira vitória do Direito sôbre o Poder, da Justiça sôbre o Arbítrio, da Lei sôbre o Cutelo e o Baraço. É Napoleão, um guerreiro dominador de homens e de impérios, quem medita e confessa: "A espada e o espírito dominam o mundo. Com o tempo a vitória pertence ao espírito".

Eis o que valem as idéias verídicas e sadias: resistem sempre à degola dos alfanges e à perfuração das carabinas. O que a História nos mostra sempre é a fôrça intrínseca do pensamento jurídico, do pensamento democráticojurídico porque só as democracias são paisagens humosas onde o Direito medra e floresce - construindo e reconstruindo civilizações sôbre as ruínas do passado bárbaro e trevoso. Construindo lentamente, mas reconstruindo sem interrupção.

Já vai longe o Sol que iluminava Platão e Aristóteles, ainda submersos nos preconceitos sociais de sua tribo, proclamando ambos o direito de escravidão do homem sôbre o homem. Mas aquele mesmo sol iluminava também a fronte de Heródoto, fixando o princípio da igualdade de todos perante a lei. Isonomia era então um neologismo grego, encerrando uma idéia jurídica nova e inédita.

Nenhum gládio pôde mutilar a palavra nascente, menos ainda sua mensagem germinada. Em Roma, Cícero retoma a fórmula jurídica-democrática, e exclama também em sua "República": "Não pode existir a liberdade, que é de todos os bens o mais dôce, quando ela não é igual para todos". A Revolução Francesa faz da "Declaração dos Direitos do Homem" um preâmbulo constitucional, uma super-constituição, e afinal asteia, em primeiro plano, a bandeira ideológica de Heródoto: a igualdade de todos perante a lei. O mundo sente e assimila a fórmula como verdade incontroversa. Nenhuma constituição liberal e democrática deixa hoje de repetí-la.

Eis o que vale uma idéia jurídica sem jaça. Eis como germina, floresce e frutifica um princípio cristalino de Direito e de Justiça. A idéia, como assinalou Bataglia, é "fattura e fattore della Storia", produto e motor da civilização. "A idéia é a mais perigosa das armas - escreveu também o Padre Leonel Franca - porque uma vez desembainhada, jamais retornará à tranquilidade de sua baínha".

Uma cátedra, Sr. Prof. Moniz de Aragão, é um laboratório de idéias. Nela, o pensamento jurídico de V. Excia. toma a forma de dogma. Circulará com seus alunos, será por êles sempre repetido. Os discípulos de hoje serão os diri- 
gentes de amanhã, serão os arquitetos de novas sociedades e de novas leis. As idéias e conceitos do mestre de hoje, o cristal de suas lições, tomarão corpo e substância amanhã, passarão do abstrato ao concreto, do espírito à validade.

Eis, Sr. Professor, a responsabilidade implacável do jurista no instante em que vivemos, acantonando pedras, cimentando os alicerces do mundo de amanhã. Mas não é tudo: toma V. Excia. posse na cátedra de Direito Judiciário Civil. Diremos, então, que a responsabilidade do mestre, nêste caso, é dupla.

O princípio da isonomia, de Heródoto, o princípio constitucional brasileiro e universal da "igualdade de todos perante a lei". é espinha dorsal da realização plena do Direito, isto é, ossatura prima de tôdas as instituições processuais. A Justiça que a humanidade aspira e clama é exatamente essa que não distingue ricos ou pobres, nobres ou plebeus, poderosos ou humildes. Só um Direito Judiciário, constantemente aprimorado, pode dar a certeza de que a balança de Temis não oscila ante o influxo dos privilégios de casta ou de fortuna.

É de suas mãos, Sr. Prof. Moniz de Aragão, que deverão sair, ilustrados de saber jurídico, mas principalmente, impregnados do sentimento íntimo de Justiça e de Equidades, os futuros dignatários da magistratura pátria, os hábeis interpretes da lei, os perfeitos arquitetos da jurisprudência. Não há responsabilidade maior assentando diretamente sôbre uma cátedra.

Mas aí não se extingue ainda a responsabilidade magisterial de
V. Excia.. Esta cátedra de Direito Judiciário Civil, desde a sua fundação até ontem, pertencia ao Professor Emérito que se jubilou com as glórias de alto saber jurídico e culminantes virtudes cívicas e morais. Esta cátedra pertenceu a Enéias Marques dos Santos, que continua a ser para nós outros, seus discípulos e seus amigos, que continuará a ser para tôdas as gerações universitárias, no presente e no futuro, exemplo constante de dignidade magisterial, de defensor intransigente da lei, da liberdade e da democracia, os três pilares de um mundo melhor.

Senhor Prof. Egas Dirceu Moniz de Aragão:

Deu-nos a egrégia Congregação a incumbência honrosa de saudar ao seu novo membro no dia de sua posse solene, na cátedra de Direito Judiciário Civil. Desejamos afiançar a V. Excia. que os títulos que o credenciam a êste cargo são tantos e tão meritórios que apenas contrastam com a mocidade de seu titular. Seus livros, seus trabalhos forenses, suas atividades didáticas, seus diversos concursos para o magistério e para a magistratura, realizados sem descanso, sem desânimo, ano após ano, demonstram invulgar pendor para 0 trato assíduo da ciência em que se especializou.

É longo e significativo o seu “currículum vitae". V. Excia. se apresenta ante as novas gerações intelectuais do Paraná como um exemplo dignificante de operosidade e justo motivo de orgulho.

Mais uma vez voltamos a nos socorrer aqui das palavras dêsse eminente mestre do Direito e da Eloqüência, que é Laertes Munhoz. 
Temos a convicção de que V. Excia. ingressa em nosso corpo docente com o entusiasmo jovem de uma inteligência já amadurecida por invejável cultura jurídica, e disposto a enfrentar, como diria Laertes, ..."o grande dever de caldear, com o fôgo de uma fé messiânica, a mentalidade desabrochante das novas gerações. E de orientá-las para a solidariedade humana, e de conduzí-las para o serviço do bem, e de encaminhá-las para o respeito das instituições que integram o patrimônio social, jurídico, político e espiritual das nações cultas".

Esta Congregação sabe que V. Excia. tem mocidade e inteligência, dignidade e honra, vocação didática e alma cívica para suster, sem esmorecimento, o volume de obrigações e deveres, que sua cátedra lhe sugere e impõe. Tem méritos vultosos e comprovados nos prélios intelectuais de dois concursos, quase simultâneos, para herdar e manter as lídimas tradições de cultura e trabalho desta Faculdade de Direito, que é também o imperecível lema de nossa Universidade do Paraná: "Scientia et Labor".

Por tudo isso, Sr. Prof. Egas Dirceu Moniz de Aragão, esta Congregação considera o ato de sua posse na cátedra de Direito Judiciário Civil um dos seus momentos mais felizes e festivos. Sente-se jubilosa a nossa Faculdade de Direito da Universidade do Paraná, com explêndidas razões, pelo motivo de sua elevação à cátedra que pertenceu a Enéias Marques".

A seguir, falou o novo catedrático, Professor Egas Dirceu Moniz de Aragão, que proferiu a seguinte oração:
"Numa de suas peripécias, em que é aliás muito fértil, o destino hoje coloca frente a seus eminentes professôres o jóvem aluno ainda incipiente no manêjo da ciência jurídica porém cheio de fé e entusiasmo, pleno de esperanças. Se por um lado êsse cruel contraste salienta a desproporção entre a minha e as figuras ilustres de renomados lentes, indicando a humildade a quem, num lance de atrevimento, ousou transpor os umbrais desta sala vindo assentarse entre vós, serve também de encorajamento ao neófito ao qual a benevolência dos mais experimentados e a condescendência dos doutos abriu um inestimável crédito de confiança que me amedronta ante o manifesto desnível entre a vossa grandeza e a minha pequeneza.

Exercem as universidades relevante papel na formação cultural dos povos. Indelével o estigma de sua ausência como indescritível o benefício de sua presença. "O surgimento das Universidades brasileiras, completas, só ultimado na década de 30, quando na América anglo-saxônica como na hispânica, o aparecimento dos cursos superiores se revestiu do seu velho conteúdo europeu, de cultura geral e religiosa, retardou de três séculos, a sistematização do pensamento nacional". Essa observação, de Munhoz da Rocha Netto, honra e glória desta Universidade, que o tem entre seus beneméritos, salienta, para lançá-los à imortalidade, os venerandos fundadores desta Casa. Êstes, numa demonstração soberba de seu espírito de escol, percebendo a importância da emprêsa e cônscios do quanto ela representava, possibilitaram através 
de esforços inenarráveis o aparecimento da primeira universidade brasileira, subsídio inestimável à inteligência nacional.

Congraçando homens de todos os rincões, sem qualquer preocupação de ordem regionalista, a Universidade do Paraná significou um especial impulso na formação duma elite espiritual. Portas abertas aos que procuram o debate das idéias ou o laborioso recolhimento da produção científica, esta Universidade realizou algo de magestoso no cenário pátrio. Aquí se temperaram ideais, cientistas se encontraram com seu destino e todos indistintamente nos favorecemos com essa invulgar contribuição prestada à integração cultural dos brasileiros.

Entretanto se ainda hoje, com o generoso apôio material que o poder público nos dispensa dada a condição de órgão federalizado, é ingente o sacrifício e incomum a renúncia exigida de nossos dirigentes universitários, é fácil imaginar que só mesmo verdadeiros titãs poderiam suplantar os obstáculos que se antepunham à concretização do desejo de oferecer ao Brasil, na Curitiba de 1912, a sua primeira universidade. Nasceu ela, por isso mesmo, sob o signo do triunfo, que só o conhecem os fortes. Nunca poderia passar-lhe pela frente o espectro do desfalecimento, tal a pujança que lhe imprimiram seus denodados criadores. A êles presto a reverência singela do meu respeito e da minha profunda admiração. E na pessôa de João Ribeiro de Macedo Filho cuja figura venerável enobreceu esta Casa e a Universidade que tanto amou e tem sua presença ainda quente na memória de todos nós, exalto o pugilo de bravos a cuja tenacidade devemos reuniões como a de hoje.

Pesada é a responsabilidade que descansa sôbre os ombros dos professôres de leis. As faculdades de direito, tal como veio a acontecer com esta, realizaram durante mais de século a obra ciclópica da formação de nossa cultura humanística. A elas e tão só a elas incumbia forjar os conhecimentos gerais e por conseqüência elaborar o pensamento nacional. A com plexidade dessa tarefa importou e necessàriamente teria de suceder, numa deformação de sua finalidade. Nem elas alcançariam o seu real objetivo de produzir bacharéis e nem tampouco poderiam atingir a outra meta, cumulada à primeira, de preparar pensadores. Daí terem surgido injustas e desastradas críticas ao "bacharelismo" do brasileiro, que se chegou a comparar às pragas que assolaram o Egito.

Errada a crítica como péssima a comparação.

Graças às faculdades de direito, e é preciso que isto se diga alto e bom som, atingiu o Brasil a posição destacada de que ontem como agora sempre desfrutou. Seus maiores vultos saíram das escolas de direito, disseminando-se pelos vários setores da atividade humana. Filósofos, sociólogos, estadistas, diplomatas, literatos, capitães de indústria, fazendeiros, em todos os lugares estava presente o rubí que nos é símbolo. $\mathrm{E}$ se mais as faculdades de direito não fizeram, culpa não lhes cabe.

Hodiernamente, entretanto, já desapareceu o motivo marcante da sobrecarga que onerava os cursos 
jurídicos. O nascimento de centros de pesquisa voltados para a formação humanística, Faculdades de Filosofia, Ciências e Letras, preenchendo assim o vazio que à sua falta impunha-se à nossa ocupar, faz que os núcleos de preparação de juristas tenham reencontrado seu verdadeiro sentido, restando apenas promover-lhe a adequação ao novo modêlo, afastados os padrões tradicionais, já superados, de molde a pô-los mais em contacto com os reclamos da realidade, aumentando-lhes a eficiência na instrução dos profissionais do direito.

Para êsse trabalho de reestruturação do ensino jurídico, sem o sentido um tanto enciclopédico que por fôrça das circunstâncias a que me referí sempre se lhe atribuiu, é que estão voltadas as atenções do momento. E caberá à nossa querida Faculdade papel ressaltado no encaminhamento da solução dêsse magno problema.

Tenho absoluta certeza de que ela não falhará a mais essa missão e o penhor seguro de minha esperança repousa no valor dos integrantes desta augusta Congregação.

Têem assento nestas bancadas juristas que são preclaros e homens que são sinceros. Se não blasonam a sua condição nem trombeteiam o próprio mérito é porque são simples e desataviados, tanto mais desataviados e simples quanto estudiosos e brilhanates. Conhecedores profundos das suas respectivas disciplinas, em que sois especialistas, como dos males que afligem $o$ ensino do direito, reunís os predicados necessários ao triunfo nesta missão de levar a Universidade ao povo, promessa de Laertes Munhoz há precisamente um decênio, porque vos sobejam qualidades para tanto. E a convicção de que será assim me atemoriza e acabrunha. É superior às minhas fôrças o encargo de cooperar convosco nesse afanoso labor.

Longe, muito longe estava da minha imaginação quando subí a escadaria - a velha e saudosa escadaria desta Csa - há uma dúzia de anos para submeter-me aos exames vestibulares, estava longe a suposição de que hoje aquí me encontraria, no tôpo da escalada, admitido por vós a vir formar ao vosso lado no doutoral, com a imensa obrigação de figurar entre vós a participar, colaborando convosco, das elucubrações de que vos ocupais. Entretanto meus professôres acreditai no jóvem e impulsivo aluno a quem conferistes o mais ambicionado galardão intelectual ao aprovardes, na Congregação reunida, o parecer da comissão examinadora que o teve como apto à regência da cátedra de Direito Judiciário Civil. Êle fará tudo para corresponder ao vosso pronunciamento. Deus permita que assim seja". 